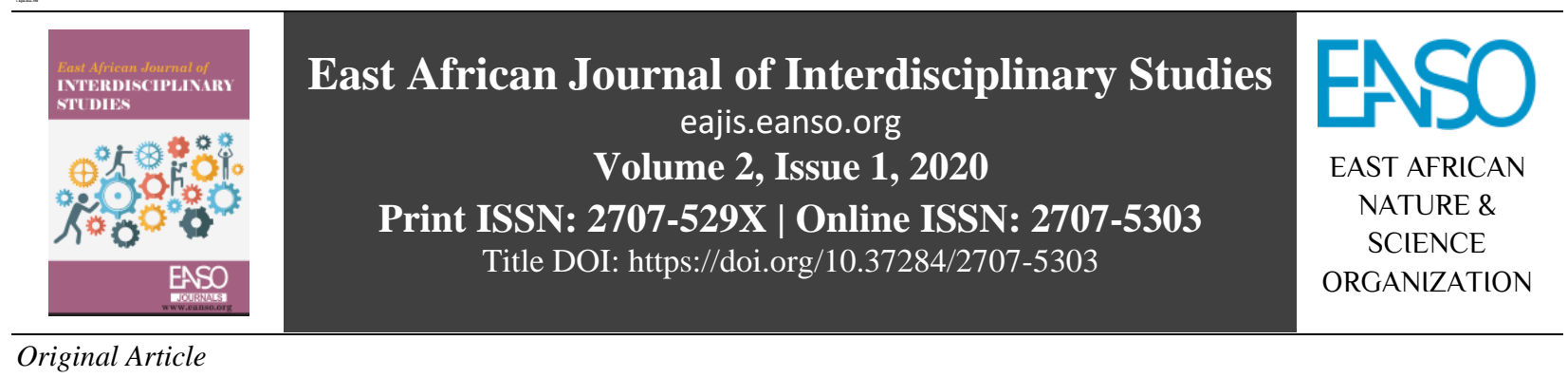

\title{
Assessment of Vulnerability and Coping Livelihood Strategies of Fishermen in Elmina, Ghana
}

\author{
Selorm A. Dzantor ${ }^{1,2, *}$, Denis W. Aheto ${ }^{1,3}$ \& Comfort O. Adeton ${ }^{2}$ \\ ${ }^{1}$ Centre for Coastal Management/Africa Centre of Excellence in Coastal Resilience, University of Cape Coast, Ghana. \\ ${ }^{2}$ Department of Geography and Regional Planning, University of Cape Coast, Ghana. \\ ${ }^{3}$ Department of Fisheries and Aquatic Sciences, University of Cape Coast, Ghana. \\ *Author for Correspondence Email: seldzantor@gmail.com
}

Article DOI: https://doi.org/10.37284/eajis.2.1.200

\section{Date Published: ABSTRACT}

28 August 2020 This study assessed the vulnerability and coping livelihood strategies of fishermen within the context of declining marine fisheries in Elmina, Ghana.

Keywords: One hundred and fifty-five (155) fishermen were purposively selected for questionnaire interviews from January to March 2017. The results showed that most of the fishermen depended heavily on fishing as a major source of

Coastal Communities, Coping,

Fishermen,

Livelihood,

Strategies,

Vulnerability. livelihood. Nonetheless, their income levels were trifled due to declining fisheries. The vulnerability index of the community proved to be significantly high. The coping livelihood strategies were largely informal, comprising farming and trading, among others. A little over half of the fishermen were willing to leave the fishing sector for different livelihoods, given other prospects. It is concluded that improving livelihoods in the community will require strengthening supplementary livelihood occupations, and educating fishers on the dangers of using illicit fishing methods are required for the growth of the sector and enhancement of income levels of fishermen.

\section{APA CITATION}

Dzantor, S., Aheto, D., \& Adeton, C. (2020). Assessment of Vulnerability and Coping Livelihood Strategies of Fishermen in Elmina, Ghana. East African Journal of Interdisciplinary Studies, 2(1), 71-88. https://doi.org/10.37284/eajis.2.1.200

\section{CHICAGO CITATION}

Dzantor, Selorm, Denis Aheto, and Comfort Adeton. 2020. “Assessment of Vulnerability and Coping Livelihood Strategies of Fishermen in Elmina, Ghana”. East African Journal of Interdisciplinary Studies 2 (1), $71-88$. https://doi.org/10.37284/eajis.2.1.200.

\section{HARVARD CITATION}

Dzantor, S., Aheto, D. and Adeton, C. (2020) “Assessment of Vulnerability and Coping Livelihood Strategies of Fishermen in Elmina, Ghana”, East African Journal of Interdisciplinary Studies, 2(1), pp. 71-88. doi: 10.37284/eajis.2.1.200. 
IEEE CITATION

S. Dzantor, D. Aheto, and C. Adeton, "Assessment of Vulnerability and Coping Livelihood Strategies of Fishermen in Elmina, Ghana”, EAJIS, vol. 2, no. 1, pp. 71-88, Aug 2020.

\section{MLA CITATION}

Dzantor, Selorm, Denis Aheto, and Comfort Adeton. "Assessment of Vulnerability and Coping Livelihood Strategies of Fishermen in Elmina, Ghana". East African Journal of Interdisciplinary Studies, Vol. 2, no. 1, August 2020, pp. 71-88, doi:10.37284/eajis.2.1.200.

\section{INTRODUCTION}

Livelihood sustainability has become an important focus within international development literature and policy debates (World Bank, 2008) and to help solve the issue of ending poverty in all forms everywhere as part of the Sustainable Development Goals (Goal 1), there is the need for livelihoods to be sustainable. In many African countries, fish is a cheap source of animal protein. Unfortunately, the contributions of fisheries to poverty reduction are threatened due to the growing scarcity of fish as a result of over-exploitation (World Fish Center, 2005). A major issue of concern is the impacts of climate change on fisheries (Rice \& Garcia, 2011; Johnson, 2012).

Climate variability and change has intensified since the 1970s and is expected to worsen in the future (Johnson, 2012). Climate change involves a complex effect that collectively modifies the natural environment and has a profound influence on the world's fisheries, most of which are likely to be negative (Johnson, 2012). These negative effects, as explained by Johnson (2012), have an effect on both the biological health and viability of fish stocks and on the safety of the financial sustainability of fishermen and fishing communities. The Sustainable Development Goal 13 urges an urgent action to be taken to help combat climate change and end its impact, especially on livelihoods of inhabitants of which fisheries are a major part of these livelihoods. In Ghana, a major effect of climate change on fisheries is the impact on upwelling, a major hydrological feature in Ghanaian marine waters (Aheto et. al., 2011). To the extent that the livelihoods of many small-scale fishers that directly depend on fisheries are under increasing threat, thereby making them vulnerable to poverty due to changes in climatic conditions (Harter et al., 2015).
Apart from climatic conditions that cause changes or the decline in the amount of fish caught by fishermen leading to their vulnerability, nonclimatic conditions also contribute to the decline of fish stocks. Illicit fishing practises such as light fishing, dynamite fishing, use of inappropriate fishing nets, pesticide fishing, bottom trawling and many others are contributing factors to a decline in fish catch. Bottom trawls are globally used fishing practice that physically disturb the seabed and kills non-target organisms, including those that are food for the targeted (Aheto et al., 2012). In Ghana, the fishing industry is regulated by rules and regulations, such as the Fisheries Act 625 of 2002 and Fisheries Regulations (L. I. 1968) of 2010 which prohibit the use of light attraction devices to catch fish and the use of dynamites and carbide for fishing. However, fishermen in the quest to catch more fishes at sea use these illegal fishing methods, leading to the destruction of fisheries resources and hence leaving them vulnerable to declining fisheries. Bottom trawl fisheries target demersal fish, crustaceans and shellfish by towing fishing gear over the seafloor, thereby not only manipulating the abundance of the target species but also physically disturbing the sea bed, damaging benthic organisms and potentially changing the functioning of the entire benthic ecosystem (Kaiser et al., 2002).

In Ghana, fishery resources are therefore under pressure largely driven by the high demand for fish products, population growth and particularly lack of alternative or coping livelihood options. Like most developing countries, Ghana's fisheries have been observed to "rhyme with poverty" because of inadequate alternative or coping livelihoods (Béné, 2003). However, fishermen in their bid to increase daily harvests to meet the demands of the populace increase fishing effort by deploying multiple numbers of gears and canoes, engage in many trips and spend longer fishing hours at sea as measures 
to reduce vulnerability. All these put excessive pressure on fishery resources, leading to their overexploitation. The threat of depletion of the resource is not only due to over-fishing but also attributable to weak regulation and ineffective management of the sector.

The introduction of an alternative means of income for fishermen or coping livelihood strategies in fishing communities could help to address the vulnerability of fishermen in fishing communities (Ofori-Danson, Apeyah, Asiedu, \& Atsu, 2012).

In this study, we explore the concept of vulnerability to be able to understand the implications and coping strategies of fishermen due to declining fisheries. Vulnerability refers to the characteristics of a person or group, events that influence their capacity to anticipate, cope with, resist and recover from the impact of a natural hazard. It involves a combination of factors that determine the degree to which someone's life, livelihood, property and other assets are put at risk by a discrete and identifiable event (or series of such events) in nature and society (Blaikie, Cannon, Davis, \& Wisner, 2014). Vulnerability also refers to the degree to which a system is susceptible to, or unable to cope with, adverse effects of climate change, including climate variability and extremes. Vulnerability is a function of the character, magnitude, and rate of climate variation to which a system is exposed, its sensitivity, and its adaptive capacity (McCarty, Canziani, Leary, Dokken \& White, 2001).

A number of studies have been carried out on the biological and economic aspects of fisheries in Ghana, but almost none has been done to assess the vulnerability of fishers and their coping livelihood strategies in that area. Aheto et al. (2012) assessed the profitability of small-scale fisheries in Elmina, Ghana. Ansah-Koi (2008) analysed wealth redistribution mechanisms in the coastal town of Moree, while Mensah (2012) looked at the optimisation of profits in the artisanal marine fishing industry. These studies conceptualise vulnerability as the result of the interactions among the threats (decline in fish due to climatic and nonclimatic factors) faced by people to their livelihoods (e.g. fishing), their capabilities (a function of their sensitivity), and the outcomes of their strategies (coping livelihoods). This paper does not specifically deal with the impacts of climate change alone but equally, recognises that livelihoods are affected by a multitude of stressors as well.

The Sustainable Livelihood Framework (DFID, 2000) was used as the conceptual framework of the study, illustrating the interactions between assets and activities. The framework places people, particularly at the centre of a web of interrelated influences that affects how these people create a livelihood for themselves and their households.

In this paper, the vulnerability context as examined from the framework is climatic (rainfall, sea-level rise, temperature, and drought) and non- climatic (illegal, unregulated and unreported fishing activities, poor sanitation, high fishing efforts, and mangrove cutting), the livelihood strategies are the coping livelihoods by the fishermen to overcome the decline in the fishing that is affecting their livelihoods.

The objective of this paper was to assess the vulnerability of fishermen and their coping livelihood strategies in Elmina in the Central Region of Ghana. The study is of high practical value aimed at providing data on these issues grounded on demographic and income information to support policy-making and serve to provide baseline data for future studies.

\section{RESEARCH METHODOLOGY}

\section{Study Area}

The study was carried out in Elmina $\left(5.1053^{\circ} \mathrm{N}\right.$, $\left.1.3421^{\circ} \mathrm{W}\right)$, the third major fishing landing site in Ghana (Figure 1). Fishing in Elmina is characterised with the use of purse seine nets, hooks and lines, bottom trawls and drift nets. Elmina was chosen for the study because it has a very long history of artisanal fishing in Ghana. The field survey was undertaken over three months (JanuaryMarch 2017). The period was chosen because it represented the lean fishing season and could demonstrate the vulnerability context and how the fishers coped during that period. One hundred and fifty-five (155) fishermen were purposively selected at the landing site at Elmina for the study. 
Figure 1: Map of Study Area Showing Elmina in the Central Region of Ghana

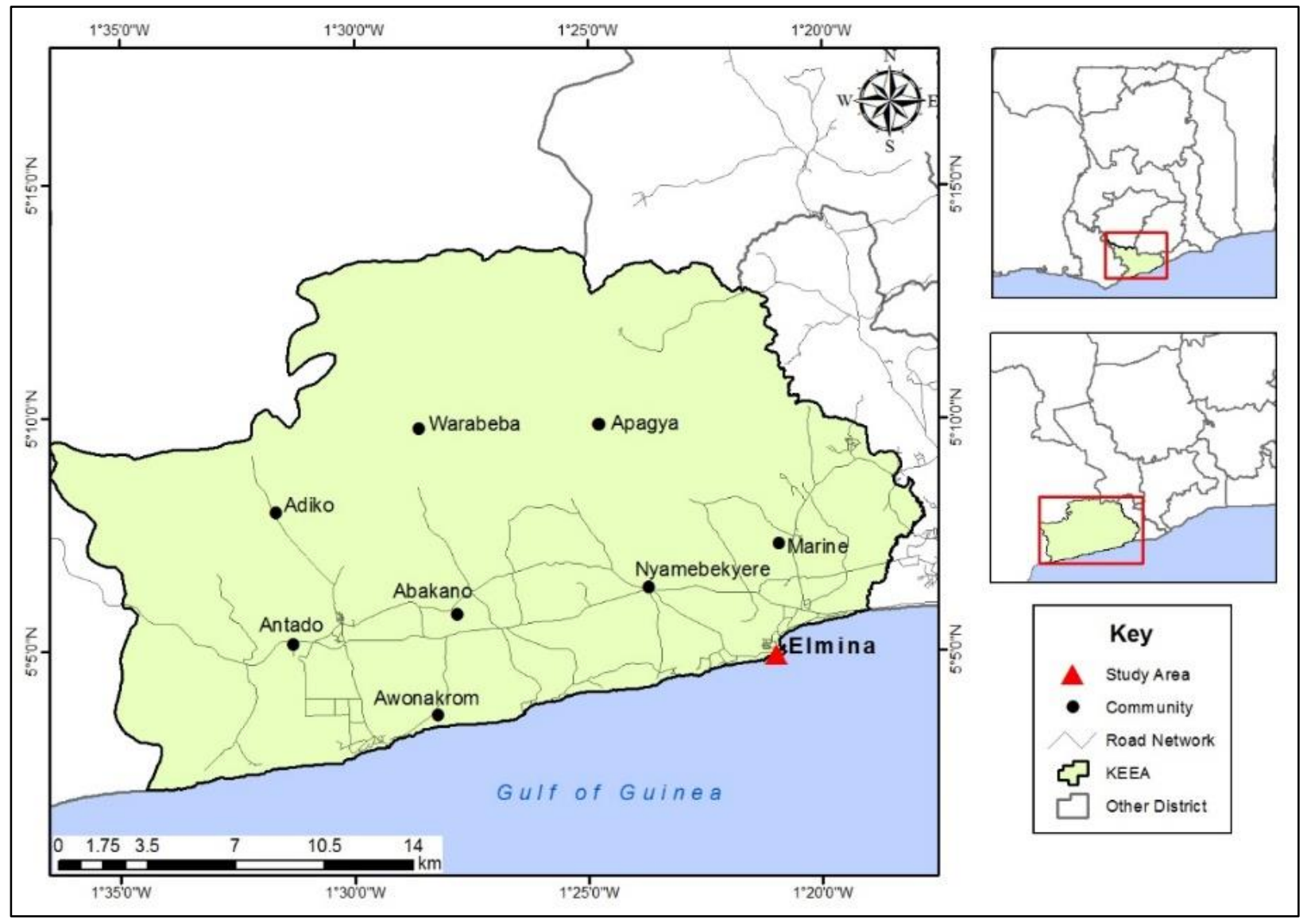

Source: GIS unit, Department of Geography and Regional Planning, UCC, 2018

\section{Data Collection and Field Survey Techniques}

Preliminary visits were made to Elmina, a convenient sample of 155 respondents were selected from the landing site at Elmina for the study. This number was used based on the availability and readiness of the respondents at the study, thus the use of a convenient sample, questionnaires were used as the research instrument to collect data from the field.

\section{Data Analysis and Statistical Tests}

Statistical Product for Service Solutions (SPSS) Version 21, the vulnerability framework, Gepphi (Version 9.0), Microsoft Excel (Version 2016) and Social Network Analysis (Knoke, \& Yang, 2008; Serrat, 2017) were used to analyse data of the respondents. The data was presented in frequencies, percentages, and tables.

Table 1: Social network dimensions and interpretation

\begin{tabular}{ll}
\hline Dimension & Interpretation \\
\hline Betweenness Centrality & Influence of an actor \\
Closeness Centrality & The closeness of an actor to every other actor \\
Degree Centrality & The connectedness of an actor or the number of connections of an actor \\
Eigenvector Centrality & Importance of an actor \\
\hline
\end{tabular}

Source: (Serrat, 2017) 
The vulnerability of the communities was evaluated based on an estimation of indices of vulnerability that were calculated as follows: the vulnerability of a community was measured as a function of exposure, sensitivity and adaptive capacity of the community (Equation 1), i.e. vulnerability $=f$ (exposure, sensitivity, adaptive capacity)

$$
\text { Vulnerability }=\mathrm{E}+\mathrm{S}+\mathrm{AC}
$$

Where $\mathrm{E}=$ exposure of the community to both climatic and non-climatic factors, $\mathrm{S}=$ sensitivity of the community in relation to the capital assets and $\mathrm{AC}=$ adaptive capacity.

\section{Estimation of Exposure}

The Exposure (E) was computed based on the measure of the relative index using the extent of observed exposure, once these factors were calculated, it was then compared to documented literature to estimate how exposed a community is to climate and/or non-climate impacts (Equation 2). For this study, the variables looked at for both the climatic and non-climatic events were; temperature, rain, flood, sea-level rise, drought (climatic factors), and mangrove cutting, high fishing efforts, poor sanitation, and illegal fishing activities (non-climatic factors).

$$
E=\frac{E_{0}}{E_{\max }}
$$

Where, Eo = observed climate and/or non-climate exposure; Emax = total score based on literature.

\section{Estimation of Sensitivity}

Sensitivity (S) was computed based on the capital assets (human, social, natural, financial, and physical) of the community (Equation 3). The concept of sensitivity is that if each community is endowed with the needed capital, then the community would be less or more sensitive to the impact of declining fisheries. A score range of 0-1 is allocated to capital assets (human, physical, natural, social and financial) available in the community. A score of 0 implies that the community is not or less sensitive. A score of 0.5 implies that there are some capital assets but not enough in the community. A score of 1 is indicative that the community is largely sensitive. Savings, remittances, access to credit, family associations were factors assessed.

$S=\frac{C A}{C_{\max }}$

Where; $\mathrm{CA}=$ observed computed sensitivity on capital, $\mathrm{Cmax}=$ documented literature

\section{Estimation of Adaptive Capacity:}

Adaptive capacity (AC) is assumed directly to be coping strategies adopted by the various fishermen in the community. Similarly, scores were awarded based on the adaptive strategies of the community against some best practices documented in the literature. A score range of $0-1$ is used, where a score of 1 implies that the adaptive capacity of the community is high and vice versa. A 0.5 score assumes that the community is putting in some efforts to adapt to changes in their basic livelihood available.

$A C=\frac{E_{0}}{O_{\max }}$

Where; $E_{0}=$ total adaptive capacity, and $O_{\max }=$ observed adapted practices

\section{RESULTS}

\section{Demographic Characteristics of the Fishermen}

In all, 155 respondents were surveyed. It was observed that some of the respondents were not residents $(31.6 \%)$ nor originated from the selected $(53.5 \%)$ study area (Elmina). Elmina was by far the dominant place of residence, representing $68.4 \%$. The largest household size of the respondent sampled is $1-5$ people in a house. Table 2 summarises the demographic data of the population. 
East African Journal of Interdisciplinary Studies, Volume 2, Issue 1, 2020

Article DOI: https://doi.org/10.37284/eajis.2.1.200

Table 2: Demographic characteristics of the sampled population

\begin{tabular}{|c|c|c|c|}
\hline \multirow[t]{2}{*}{ Demography } & \multirow[t]{2}{*}{ Category } & \multicolumn{2}{|c|}{ Respondents $(n=155)$} \\
\hline & & $\mathbf{F}$ & $\%$ \\
\hline \multirow[t]{9}{*}{ Place of residence } & Elmina & 106 & 68.4 \\
\hline & Apam & 4 & 2.6 \\
\hline & Winneba & 1 & 0.6 \\
\hline & Cape Coast & 23 & 14.8 \\
\hline & Anomabo & 8 & 5.2 \\
\hline & Shama & 2 & 1.3 \\
\hline & Saltpond & 8 & 5.2 \\
\hline & Komenda & 2 & 1.3 \\
\hline & Abandze & 1 & 0.6 \\
\hline \multirow[t]{13}{*}{ Place of Origin } & Elmina & 72 & 46.5 \\
\hline & Moree & 1 & 0.6 \\
\hline & Biriwa & 1 & 0.6 \\
\hline & Apam & 10 & 6.5 \\
\hline & Winneba & 4 & 2.6 \\
\hline & Cape Coast & 29 & 18.7 \\
\hline & Anomabo & 18 & 11.6 \\
\hline & Abandza & 2 & 1.3 \\
\hline & Tema & 3 & 1.9 \\
\hline & Ada & 1 & 0.6 \\
\hline & Shama & 6 & 3.9 \\
\hline & Saltpond & 6 & 3.9 \\
\hline & Komenda & 2 & 1.3 \\
\hline \multirow[t]{4}{*}{ Marital Status } & Married & 122 & 78.7 \\
\hline & Single & 16 & 10.3 \\
\hline & Divorce & 13 & 8.4 \\
\hline & Widower & 4 & 2.6 \\
\hline \multirow[t]{6}{*}{ Age } & $18-29$ & 23 & 14.8 \\
\hline & $30-39$ & 39 & 25.2 \\
\hline & $40-49$ & 52 & 33.6 \\
\hline & $50-59$ & 22 & 14.2 \\
\hline & $60-69$ & 12 & 7.7 \\
\hline & 70 and Above & 7 & 4.5 \\
\hline \multirow[t]{4}{*}{ Household size } & $1-5$ & 80 & 51.6 \\
\hline & $6-10$ & 61 & 39.4 \\
\hline & $11-15$ & 13 & 8.4 \\
\hline & $16-20$ & 1 & 0.6 \\
\hline \multirow[t]{6}{*}{ Level of Education } & None & 48 & 31 \\
\hline & Primary & 57 & 36.8 \\
\hline & JHS & 29 & 18.7 \\
\hline & SHS & 8 & 5.2 \\
\hline & Tertiary & 2 & 1.3 \\
\hline & A-Level & 11 & 7.1 \\
\hline Primary Occupation & Fishing & 155 & 100 \\
\hline \multirow[t]{6}{*}{ Secondary Occupation } & Trader & 1 & 0.6 \\
\hline & Constructional work & 4 & 2.6 \\
\hline & Farming & 4 & 2.6 \\
\hline & Sea Food Business & 3 & 1.9 \\
\hline & Piggery & 1 & 0.6 \\
\hline & $\begin{array}{l}\text { Artisans work } \\
\text { (e.g. carpentry) }\end{array}$ & 15 & 9.7 \\
\hline Income from Fishing (US\$/month) & $2.34-117.1$ & 86 & 55.4 \\
\hline
\end{tabular}


East African Journal of Interdisciplinary Studies, Volume 2, Issue 1, 2020

\begin{tabular}{clll}
\hline Demography & Category & \multicolumn{2}{l}{ Respondents $(\mathbf{n = 1 5 5})$} \\
& & F & \% \\
\cline { 2 - 4 } & $117.3-234.2$ & 41 & 26.5 \\
& $234.4-351.3$ & 7 & 4.5 \\
& $351.5-468.4$ & 7 & 4.5 \\
\hline & 468.6 and above & 14 & 9 \\
\hline Overall Income (US\$/month) & $2.34-117.1$ & 73 & 47.1 \\
& $117.3-234.2$ & 44 & 9 \\
& $234.4-351.3$ & 7 & 4.5 \\
& $351.5-468.4$ & 17 & 11 \\
\hline
\end{tabular}

Note: $n=$ Response, \%= Response rate, US\$ rate as at 2017, 1 dollar to 4.2702 cedi

Most respondents were married (78.8\%). The mean average active age involved in fishing activities was 40-49 years representing $33.6 \%$ of the respondents. However, age groups 60-69 and 70 years and above both had the least respondents involved in fishing in the community sampled representing 7.7 and $4.5 \%$, respectively. This depicts how the aged were less involved in fishing activities in the community. The data also shows less involvement of the age groups 18-29 years in fishing with a percentage of 14.8, depicting how the youth were also less involved in fishing activities.

The overall income of the fishermen was evaluated for the period January to March in 2017. This factor is an aggregate sum of income from fishing and other sources such as alternative livelihood (farming, trading, seafood business, salt mining, animal husbandry and others) apart from fishing and remittances. The data is evident that most of the respondents had no additional source of income apart from the income generated from fishing. Thus, the overall income of the fishermen was not different from their income from fishing. A large proportion of the respondents made a range of $\$ 2.34$ - \$117.1 as an overall income gained. However, an insignificant number of the respondents had extra sources of income apart from income obtained through fishing.

\section{Vulnerability Assessment of Elmina}

The vulnerability was assessed to estimate how the community was vulnerable to declining fisheries and the need for some coping livelihoods.

Table 3: Estimation of the vulnerability of the fishers to declining fisheries in the community

\begin{tabular}{lllll}
\hline Community & Exposure & Sensitivity & Adaptive capacity & Vulnerability \\
\hline Elmina & 0.496 & 0.452 & 0.024 & 0.972 \\
\hline
\end{tabular}

The vulnerability measure is determined on a scale of $0-1.0$, where $0 \geq 0.4$ implies that the community is less vulnerable, $0.5 \geq 0.7$ refers to the community being moderately vulnerable and $0.8 \geq 1.0$ means the community is highly vulnerable. From the data computed, it was realised that the fishermen in the study area (Elmina) are highly vulnerable (Table 3). The vulnerability index of 0.972 of Elmina indicates that they are highly vulnerable to declining fisheries.
Elmina had a sensitivity level of 0.452 and a very low adaptive capacity. The low level of the adaptive capacity (coping livelihoods) of the community, coupled with the moderate exposure to declining fisheries leaves the community to be highly vulnerable to declining fisheries in the study area. Some of the adaptive capacity identified among the fishermen in Elmina included farming, seafood processing and other coping livelihoods in catering for their families should their fishing sector be exposed to climatic and non-climatic threats. 
Figure 2: Social Network Analysis of Elmina to estimate demographic factors accounting for the observed vulnerability of the fishing population

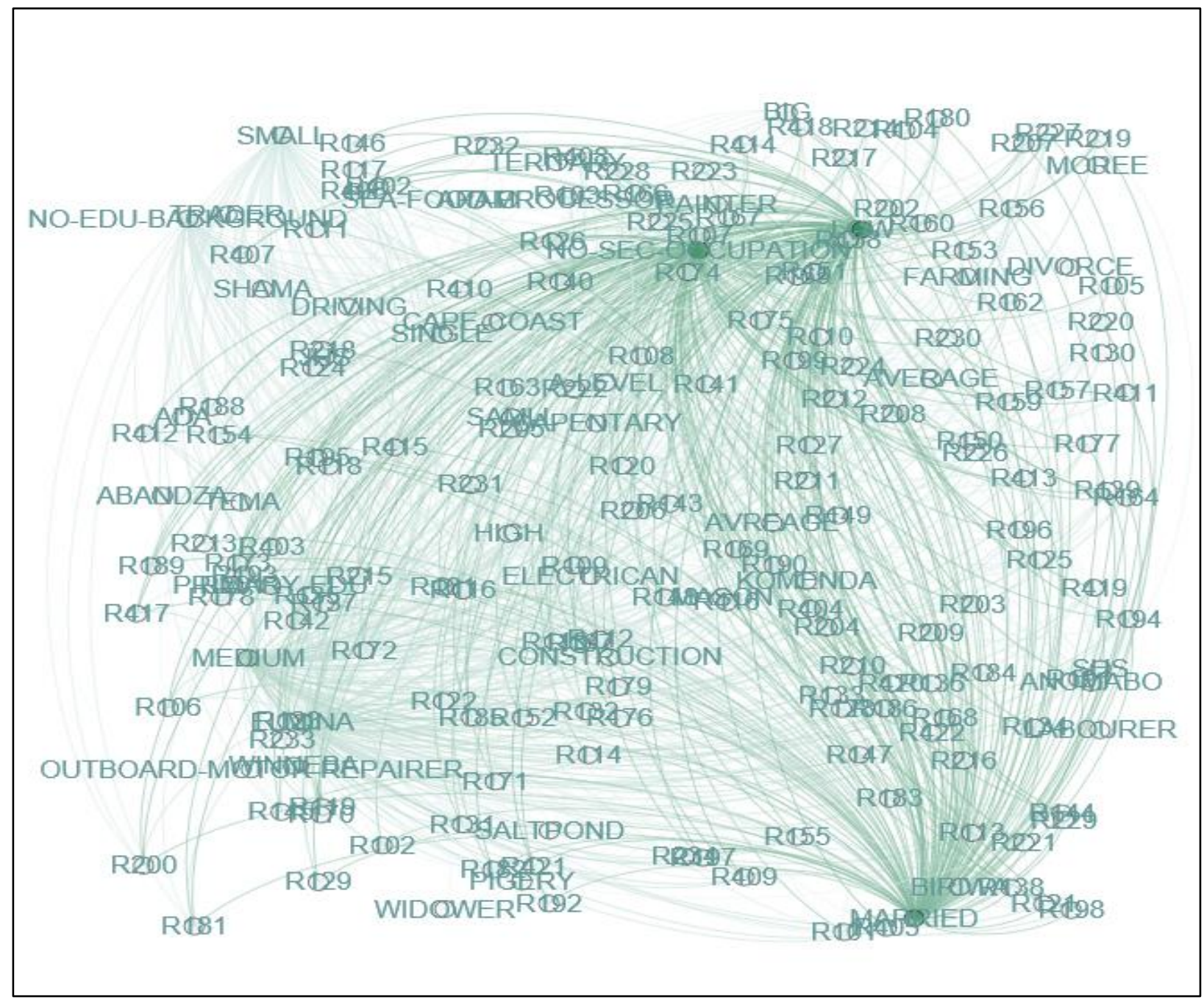

Table 4: Key actors within fishermen in Elmina

\begin{aligned} & \hline Dimension Actors with supporting values \\ & \hline Most influential actors Low income (4975.7) \\ & Married (4208.6) \\ & No secondary occupation (3742.0) \\ & \hline Closest actor to every other actor in the network Low income (0.69) \\ & Married (0.63) \\ & No secondary occupation (0.61) \\ & \hline Most connectedness actor in the network Low income (135) \\ & No secondary occupation (125) \\ & Married (122) \\ & \hline\end{aligned}

\footnotetext{
${ }^{1}$ The concentration at a particular node denotes a high number of respondents being affected by that particular parameter in the study, i.e, majority of respondents sampled were married, had low income and had no secondary occupation and thus a lot of convergence at that node. ' $R$ ' represents the respondent sampled
} 


\begin{aligned} & \hline Dimension Actors with supporting values \\ & \hline Most important actor in the network Low income (1.0) \\ & No secondary occupation $(0.9) \\ &$ Married $(0.9) \\ &$\hline\end{aligned}

From Table 4, it can be deduced that the most important and influential factor driving fisheries exploitation is the low-income status of the fishers. Even though married respondents were the second most influential factor, it was not confirmed to be more important than the secondary occupation. The least actors in the communities in terms of influential, the closest actor, the most connected and the most important actor in the SNA proved to be the informal activities engaged in by the respondents, an indication of low adaptive capacity of the respondents to other livelihoods apart from fishing.

Figure 2 is an evidence of how low-income levels of the community is the most influential and important actor in the SNA as the majority of the respondents represented by edges aggregated to a particular node (low-income) in the community.

Table 5: Savings of fishermen and the purpose of saving

\begin{tabular}{lllll}
\hline Savings of fishermen & $\begin{array}{l}\text { Purpose of savings } \\
\text { Payment of school } \\
\text { fees }\end{array}$ & $\begin{array}{l}\text { Building } \\
\text { project }\end{array}$ & $\begin{array}{l}\text { Future } \\
\text { uncertainty }\end{array}$ \\
\hline Yes & $118(76.1 \%)$ & $89(57.4 \%)$ & $19(12.2 \%)$ & $10(6.5 \%)$ \\
No & $37(23.9 \%)$ & 0 & 0 & 0 \\
\hline
\end{tabular}

It was found out that, $76.1 \%$ of the sampled population saved whiles the remaining $23.9 \%$ did not save any proceeds from their sale of fish. While $57.4 \%$ of the respondents used their savings to pay school fees of their children and this has the potential to strengthen the human capital of their wards and the nation at large.

Table 6: Remittances and amount received

\begin{tabular}{|c|c|c|c|c|c|}
\hline \multirow{2}{*}{\multicolumn{2}{|c|}{ Remittance received }} & \multicolumn{4}{|c|}{ Amount received as remittance } \\
\hline & & $\begin{array}{l}\text { Less than } \\
\text { US\$ 11.7 }\end{array}$ & $\begin{array}{l}\text { US\$ } \\
23.4\end{array}$ & $\begin{array}{l}\text { US\$ } 23.7- \\
35.1\end{array}$ & $\begin{array}{l}\text { US\$ } 35.4 \\
\text { and above }\end{array}$ \\
\hline Yes & $31(20 \%)$ & $5(3.2 \%)$ & $16(10.3 \%)$ & $6(3.9 \%)$ & $4(2.6 \%)$ \\
\hline No & $124(80 \%)$ & 0 & 0 & 0 & 0 \\
\hline
\end{tabular}

US\$ rate as at 2017, 1 dollar to 4.2702 cedi

Issues of remittances were looked at in the research to assess the financial strength of the respondents. Remittances received were the least added income to the fishermen as the majority of them did not receive any income from remittances. About 124 $(80 \%)$ of the sampled respondents did not receive any form of remittance from relatives elsewhere. However, the remaining $20 \%$ received remittances.
Table 6 shows that the highest amount of money received by the respondents from remittance was above US\$ 35.4 and respondents that received this amount was $2.6 \%$. However, a portion $(10.3 \%)$ of the respondents who received remittances in the study area, received between US\$11.7 - \$23.4, the least remittance received was less than US\$ 11.7. 
East African Journal of Interdisciplinary Studies, Volume 2, Issue 1, 2020

Article DOI: https://doi.org/10.37284/eajis.2.1.200

Table 7: Access to bank credit and the amount received

\begin{tabular}{llllll}
\hline Access to bank credit & & \multicolumn{4}{c}{ Amount of loans received from banks } \\
& & Less than & US\$ 46.8- & US\$ 93.9- & US\$ 140.7 \\
& & US\$ 46.8 & $\mathbf{9 3 . 8}$ & $\mathbf{1 4 0 . 5}$ & and above \\
\hline Yes & $33(21.3 \%)$ & $11(7.1 \%)$ & $5(3.2 \%)$ & $7(4.5 \%)$ & $10(6.5 \%)$ \\
No & $122(78.7 \%)$ & 0 & 0 & 0 & 0 \\
\hline
\end{tabular}

US\$ rate as at 2017, 1 dollar to 4.2702 cedi

To the question of whether fishermen had access to bank credit, $78.7 \%$ of the respondents answered affirmatively that they had no access to credit facilities from the banks. The few $(21.3 \%)$ that had access to these banks and other financial union credits were privileged to credit access ranging from US\$ 46.8 to above US\$ 140.5 (Table 7).

Table 8: Expenditure of fishermen per trip in both minor and major seasons

\begin{tabular}{lll}
\hline Ranges (US\$) & Frequency & Per cent \\
\hline Less than 11.7 & 3 & 1.9 \\
$11.7-23.4$ & 2 & 1.3 \\
$23.6-35.1$ & 11 & 7.1 \\
35.4 and more & 139 & 89.7 \\
Total & 155 & 100 \\
\hline
\end{tabular}

US\$ rate as at 2017, 1 dollar to 4.2702 cedi

Fishing expenditure at sea was calculated, it was revealed that majority of the respondents spent above US\$ 35.4 on trips for fishing during both the minor and major seasons at sea. Some of the respondents, however, spent less on a fishing expedition (Table 8).

Table 9: Amount made per fishing trip

\begin{tabular}{lll}
\hline Ranges (US\$) & Frequency & Percent \\
\hline Less than 11.7 & 2 & 1.3 \\
$11.7-23.4$ & 5 & 3.2 \\
$23.6-35.1$ & 70 & 45.2 \\
35.4 and more & 78 & 50.3 \\
Total & 155 & 100 \\
\hline
\end{tabular}

US\$ rate as at 2017, 1 dollar to 4.2702 cedi

Respondents noted that the amount they had from fishing per trip was low and at times the incurred losses. Respondents sampled representing $45.2 \%$ made a range of US\$ $23.7-\$ 35.1$ while less than two per cent of respondents made about US\$ 11.7 per trip. The total amount realised from the sales of fish can be attributed to the reduction in the total fish catch per a fishing trip.

\section{Assess the Coping Livelihood Strategies Adopted by Fishermen}

The state of the fisheries resources was studied to assess whether there was any reduction in the stock of fish. A significant proportion (146, 94.2\%) of the respondents specified that there was a reduction in the fish stock over the past 10 years. However, less than six percent ( 9 respondents) of the total sampled respondents observed that their catches of fish over the past ten years had been the same.

Respondents acknowledged a reduction in the stock of fish over the past 10 years mentioning a dwindling catch recorded and attributed the cause for the reduction of fish stock to both climatic and non-climatic factors (Table 10). 
Table 10: Causes for a reduction in fish stocks in the communities

\begin{tabular}{lll}
\hline Categories & Frequency & Percent \\
\hline Light and dynamite fishing & 33 & 21.3 \\
Industry trawlers & 57 & 36.8 \\
Light fishing and big trawlers & 23 & 14.8 \\
Increased population of fishermen & 17 & 11.0 \\
Nature effect on fish & 11 & 7.1 \\
Light fishing & 4 & 2.6 \\
Dynamite fishing and big trawlers & 1 & 0.6 \\
No response & 9 & 5.8 \\
Total & 155 & 100 \\
\hline
\end{tabular}

Table 11: Type of productive venture fishers are involved

\begin{tabular}{lll}
\hline Categories & Frequency & Percent \\
\hline Farming & 3 & 1.9 \\
Piggery & 2 & 1.3 \\
Constructional work & 5 & 3.2 \\
Trading & 2 & 1.3 \\
Carpentry & 4 & 2.6 \\
Seafood business & 2 & 1.3 \\
Mason & 2 & 1.3 \\
Driving & 1 & 0.6 \\
Painting & 1 & 0.6 \\
Outboard motor repairs & 2 & 1.3 \\
Labourer & 2 & 1.3 \\
No response & 129 & 83.2 \\
Total & 155 & 100 \\
\hline
\end{tabular}

Out of the 155 respondents, $16.8 \%$ were involved in other productive ventures as coping livelihood strategies apart from fishing. Out of the $16.8 \%$ of the sampled population with coping livelihoods, less than three percent of the respondents were traders. Farming, piggery, constructional work, seafood processors, and driving constituted other coping livelihoods adopted by the fishermen to help earn extra income to cater for their families and household.

The research further analysed the reasons for $16.8 \%$ of the respondents engaging in other productive ventures. The main reason for engaging in other coping livelihoods, as reported by the respondents is reduced income from fishing. The findings on reduced income from fishing conform to the report of the FAO (2006) stipulating the low income gained from fishing. Fishers moved into different ventures because the income from fishing was small and could not solely help them cater for their families' livelihood and hence the need for other coping livelihoods. From the conceptual framework, the vulnerability context influencing the livelihood assets such as their natural capital (fish) leading to a decline in fish will lead the fishermen to diversify into another livelihood as a motivating factor.

Table 12: Reasons for fishermen choice of preference in another coping livelihood

\begin{tabular}{lll}
\hline Categories & Frequency & Percent \\
\hline Fishless profitable & 2 & 1.3 \\
Less risky as compared to fishing & 3 & 1.9
\end{tabular}


East African Journal of Interdisciplinary Studies, Volume 2, Issue 1, 2020

Article DOI: https://doi.org/10.37284/eajis.2.1.200

\begin{tabular}{lll}
\hline Categories & Frequency & Percent \\
\hline Lived all my life fishing & 14 & 9.0 \\
Earn more from fishing than my other job & 7 & 4.5 \\
No response & 129 & 83.2 \\
Total & 155 & 100 \\
\hline
\end{tabular}

Reasons adduced for the choice of other coping livelihoods aside fishing included; less profitability of the fish, and the risky nature of the fishing industry. The study assessed whether fishermen liked their livelihood option to fishing or preferred fishing instead. Out of the 26 respondents representing $16.8 \%$ who stated that they had a coping livelihood strategy, (21) $13.5 \%$ of the total sampled population made it clear that they preferred fishing to their coping livelihood strategy. They gave reason such as; monies earned from fishing was more than from their coping livelihood strategies and also, some of the respondents stated they had fished as an occupation all their life and as such preferred fishing as an occupation than their coping livelihood. Less than four per cent of the $16.8 \%$ who had a coping livelihood occupation preferred their coping livelihood to fishing and gave reasons such as; fishing was no more a profitable job and their coping livelihood was less risky to fishing (Table 12).

Table 13: Fishermen given the opportunity to do other productive venture

\begin{tabular}{lll}
\hline Categories & Frequency & Percent \\
\hline Yes, because catch and income from fish is low & 86 & 55.5 \\
No, because of less skills in other jobs & 14 & 9.0 \\
Yes, because fishing is too risky and difficult & 13 & 8.4 \\
No, because I have lived all my life fishing & 12 & 7.7 \\
No, because I am aged & 4 & 2.6 \\
No response & 26 & 16.8 \\
Total & 155 & 100 \\
\hline
\end{tabular}

Fishermen who had no productive venture as a coping livelihood, representing $83.2 \%$ of the respondents were asked if they would leave the fishing industry for a different venture if given the opportunity. Out of this number, $55.5 \%$ of the sampled responded in the affirmative. This is due to low catch and income from fishing and as such, will leave for a different livelihood if given the opportunity. About $8.4 \%$ also stated they would leave the fishing industry because the job is too risky and difficult. Fishermen were, however, willing to switch jobs.

Table 14: Current fisheries resource status

\begin{tabular}{lll}
\hline Fish resource & Frequency & Percentage \\
\hline Poor & 135 & 87.1 \\
Good & 18 & 11.6 \\
Very good & 2 & 1.3 \\
Total & 155 & 100 \\
\hline
\end{tabular}

The field data in Table 14 showed that the status of the stock in fish has declined as the majority of the respondents $(87.1 \%)$ agreed to the fact that the nature of their fisheries resources was poor, 11.6 percent of the respondents, however, said it was good with only $1.3 \%$ indicating that it is very good. 


\section{DISCUSSION}

The level of education of the respondents was generally low, with the majority of the fishers having only primary education. This observation is typical of fishing communities as reported by Olago et al. (2007). Migration among fishers was evident in the study area as a lot more of the fishers migrated from relatively short distances to fish in the study area (Elmina) which support the argument put forward by Siddiqui (2012), that people tend to engage more in shorter distance (internal) migration. This further goes to support Ravenstein's first law of migration that "most migrants move only a short distance" (Ravenstein, 1885) to fish at the selected fishing community. However, the findings also buttress the assertion that many people are on the move to alternative locations in search of better economic activities and this has made migration an integral part of the current global economy (De Haan, 1999; De Jong, \& Gardner, 2013; United Nations, 2015; International Organisation for Migration, 2016).

High financial risk as stipulated by Sethi (2010) among fishers as a result of low fish catch was evident in the study. The analysis made on the income levels of the fishers proved that income generated was as low as US\$2.34 to 117.1 for some fishermen in a month, which is attributed to the decline in catch of fish. The low income of fishers prevented some of the fishermen from saving any proceeds from their sales. However, those that saved, channelled it towards the development of their children's education. This was observed to be so because several of the fishermen do not want their children to become fishermen as they do not foresee any good future in the activity. It appears this trend is becoming a growing practice among fishermen in several fishing coastal communities (Fraga et al., 2008). Other reasons for the lack of savings included investment in the construction of houses, and future uncertainties. The low saving culture of the fishermen in the study area supports the argument by FAO (2006) that, there is low saving culture due to less income from fish caught in fishing communities.

In addition, fishers acknowledged their inability to access credit facilities, making it difficult to invest in their fishing business and this leads to low income. This finding corroborates the works of Kydd and Dorward (2001), who intimated that, inadequate financial capital among fishermen limits their seasonal liquidity needs to invest in the fishing sector. Also, Wilk, Andersson, and Warburton (2013) concluded that the lack of availability of loans and access to bank credit for fishermen in fishing communities leads to the vulnerability of individuals and households. Inadequate financial capital among fishermen limits their seasonal liquidity needs to invest in the fishing sector (Kydd, \& Dorward, 2001). Olago et al. (2007); Iwasaki et al. (2009); Shauri (2014) noted that there were constraints that result from limited physical infrastructure and access to basic services like credit that characterize most fisher communities making them unable to access bank credits. A reduction in financial capital results in lower coping capacity, hence increased vulnerability of fishermen (Bunce, Rosendo, \& Brown, 2010).

The assessments of vulnerability consider that social groups (e.g. fishermen) in communities are not equally vulnerable and that the differences in vulnerability result from the differences in attributes, such as sex, social class (wealth), education, ethnicity, health, availability of coping livelihoods, degree of exposure to climatic and nonclimatic factors and others (FAO, 2008). The study area recorded a high degree of vulnerability, with most fishers exposed to declining fishers because of climatic factors because of their very low adaptive capacity and as such most fishers do not have any livelihood option to diversify to should fisheries resources decline. These findings conform to the conceptual framework of the study which explains how the vulnerability context can affect the livelihood assets and finally the outcome of one's strategies leading to the vulnerability of individuals and households (DFID, 2000).

Decreased revenues for fishermen due to the decline in total catch and stock abundance are commonly cited as a consequence of natural disasters and climate variability (Lum Kong, 2002; Mahon, 2002). Doing a comparative analysis with the amount spent on fishing trips and the amount gained, it was realized that a lot spent more monies on fishing trips than the amount they gained from each trip which indicates less profitability of the fishing industry as an occupation (Aheto et al., 
2012). The reduction in the stock of fish which contributes to the reduction in income of the fishermen over the past 10 years is evident in the 2016 report of the FAO which stated that fish production in Ghana fell from 1,614,536 tonnes in 2013 to $1,559,746$ tonnes in 2014. This further supports the findings of Fjellheim, and Johnsen (2001) on the decline of stock of fish over the years.

These reductions in the stock size of fish are evident in the works of Aphunu and Nwabeze (2012) where it was confirmed that flood (natural disasters) can cause a reduction in the tonnes of fish at sea. Also, climate variability and change through sea-level rise, storminess and floods can lead to a decreased amount of fish caught over the years (Lum Kong, 2002). Further inferring from the conceptual framework, the vulnerability context (trends, shocks and seasonality) which relates to the climatic and non-climatic events examined in the study have an effect on the natural assets (fish) of the fishermen leading to a reduction in the stock of fish. Thus, changes in the availability of fish products (natural capital) can affect total revenues and harvesting costs (net revenues) of fishermen which may result from effects from the impact of climatic and non-climatic events on the natural capital, (DFID, 2000). The causes for the reduction in fish stock were evaluated and most of the issues that came up included the use of light fishing and dynamite, the effect of big industrial trawlers, natural causes on the sea which is evident in the works of Aphunu, and Nwabeze, (2012) where it was recorded that flood (natural disasters), damage tonnes of fish catch, increase in the population of the fishers at sea were major factors attributed to the reduction in the stock of fisheries resources over the years.

This study reveals that the exogenous factors exist in small-scale fisheries of Ghana and plays a role in how fishers respond to fluctuations in the fishery, by intensifying light fishing and dynamite fishing which were the second predominant causes of the decline in the fish stocks apart from destruction by the industrial trawlers over the past years. This finding is evident in the work of Aheto et al. (2012) where, they found out that, bad fishing practises such as light fishing, dynamite fishing, use of inappropriate fishing nets, pesticide fishing, bottom trawling and many others are contributing factors to decline in the total fish catch. Industrial trawlers which registered as the highest cause of the reduction in the stock of fish can be seen as a globally used fishing gear that physically disturb the seabed and kill non-target organisms, including those that are food for the targeted. This is also consistent with, the work of Hinz et al. (2009). However, other causes for the reduction in the stock of fish identified were an increase in the number of fishermen at sea, and dynamite fishing also contribute to these declines.

One area that should be taken into serious consideration is the provision of alternative livelihoods, many of the respondents are without alternative livelihood options, however, there are inadequate options to diversify to other livelihoods in the community which is somewhat attributed to low qualification and skills to secure other coping livelihoods. Therefore, any well-designed alternative livelihood scheme will have to address how to improve suitable skills among fishers, given the concern expressed by fishers that current alternative livelihood options in other sectors required some skills which were lacking to them as fishermen. This is evident in Charles's (2001) study that reported that "Solving the problem of a lack of livelihood diversity (economic diversification) is by no means simple, if it were, fishery-based economies would already have become diversified by now, in response to past fishery downturns". As stated by Thorpe et al. (2007), fishing is just one component of the portfolio of activities to support fishers' livelihoods and thus the need to have other alternative livelihoods. Daw, Cinner, McClanahan, Brown, Stead, Graham and Maina (2012) also found out that fishermen with livelihood options were more likely to exit when there is declining fishery. Hence quite a number of the respondents were found in other productive ventures, diversification seems also to be a positive factor of economic development, as suggested by the relation between the number of activities undertaken by these fishermen and for these respondents who switched jobs when fish declined, small scale fisheries, livelihood provision must not be toward increasing production (still within the fishing sector) but rather toward livelihood diversification to other sectors for livelihood security as well as environmental sustainability (Allison, \& Ellis, 2001). The findings on the coping 
livelihoods of the fishermen support the conceptual framework on how people are likely to look for other livelihoods (livelihood strategies) to earn more income, increase their well-being, help reduce vulnerability and improve their food security (livelihood outcomes) to cater for their families and households (DFID, 2000).

In general, this study shows that a sizable number of fishers are willing to pursue alternative livelihoods, which may imply that there may be a good potential for well-designed alternative livelihood schemes to succeed which will help solve the issues of reducing hunger and eradicating poverty which forms part of the Sustainable Development Goals 2 and 1 respectively. Some of the fishermen, however, stated they will not leave the fishing industry and gave reasons such as; they were aged, they had no skill for another job apart from fishing and also, they had lived all their life fishing and cannot do another job. Realistically, the change of livelihood of the fishermen in times of less catch from the sea and the low income associated with it calls for the involvement of the fishermen in other productive ventures which conforms to the findings of Whittingham et al. (2003) and Claire (2004) that most fishermen are involved in private business aside fishing to help them cater for their families. A move to a different livelihood when crises sets in is evident in the works of Sethi (2010) that, fishing is a risky business.

\section{CONCLUSION}

The study has shown that, the vulnerability of Elmina proved to be significantly high. Source of income to fishermen from fishing is low and most fishermen without coping livelihoods depended heavily on income from fishing to cater for themselves and their families. Moreover, fishermen were willing to leave the fishing sector for different livelihoods, given other prospects with reasons ranging from the highly risky nature of fishing to low income gained from the fishing sector. These results imply that there is the potential for welldesigned coping livelihood schemes but the few $(19.4 \%)$ who opted to stay in the sector regardless of the poor nature of income raised concerns of being aged and did not have the required skills to work outside the fishing sector. Therefore, any well-designed coping livelihood scheme will have to address how to improve suitable skills among fishers.

It is recommended that there should be formal training in other livelihood options especially among the youth to stay away from fishing and that could also go a long way to help fishers attain skills to diversify into other livelihoods with ease, attempts should also be made in controlling the increasing fishing pressure and effort, use of light and dynamites in fishing and regulating the big industrial trawlers at sea. This will help the artisanal fishermen to increase their catch. Seasonal sea closures are also encouraged to be implemented. When this is implemented, it will help the fish to fallow and bring forth a lot of fish. Alternative livelihoods will be the best option to help and encourage fishermen dependent on fishery resources to move to other productive ventures especially in the lean season of fishing.

\section{REFERENCES}

Aheto, D. W., Asare, N. K., Quaynor, B., Tenkorang, E. Y., Asare, C., \& Okyere, I. (2012). Profitability of small-scale fisheries in Elmina, Ghana. Sustainability, 4(11), 27852794.

Aheto, D. W., Mensah, E., Aggrey-Fynn, J., Obodai, E. A., Mensah, C. J., Okyere, I., \& Aheto, S. P. K. (2011). Spatio-temporal analysis of two coastal wetland systems in Ghana: Addressing ecosystem vulnerability and implications for fisheries development in the context of climate and land use changes. Archives of Applied Science Research, 3(3), 499-513.

Allison, E. H., \& Ellis, F. (2001). The livelihoods approach and management of small-scale fisheries. Marine Policy, 25(5), 377-388.

Ansah-Koi, N. A. (2008). Ibi Tse Yie (Some people are better off): Wealth re-distribution mechanisms in the coastal town Moree, Ghana. Unpublished master's thesis, University of Bergen, Bergen, Norway.

Aphunu, A., \& Nwabeze, G. O. (2012). Fish farmers' perception of climate change impact 
on fish production in Delta State, Nigeria. Journal of Agricultural Extension, 16(2), 1-13.

Béné, C. (2003). When fishery rhymes with poverty: A first step beyond the old paradigm on poverty in small-scale fisheries. World Development, 3(1), 949-975.

Blaikie, P., Cannon, T., Davis, I., \& Wisner, B. (2014). At risk: natural hazards, people's vulnerability and disasters. Routledge.

Bunce, M., Rosendo, S., \& Brown, K. (2010). Perceptions of climate change, multiple stressors and livelihoods on marginal African coasts. Environment, Development and Sustainability, 12(3), 407-440.

Charles, A. T. (2001). Sustainable fishery systems. Oxford: Blackwell Science.

Claire, I. (2004). Alternative sustainable livelihoods for coastal communities: A review of experience and guide to best practice. London: IUCN.

Daw, T., Cinner, J. E., McClanahan, T. R., Brown, K., Stead, S. M., Graham, N. A. J., \& Maina, J. (2012). To fish or not to fish: Factors at multiple scales affecting artisanal fishers; readiness to exit a declining fishery. PLoS One $7(2), 34-40$.

De Haan, A. (1999). Livelihoods and poverty: The role of migration: A critical review of the migration literature. The Journal of Development Studies, 36(2), 1-47.

De Jong, G. F., \& Gardner, R. W. (Eds.). (2013). Migration decision making: multidisciplinary approaches to microlevel studies in developed and developing countries. Elsevier.

Department for International Development (DFID). (2000). Sustainable livelihoods guidance sheets. London: Department for International Development. Available at . https://www.livelihoodscentre.org/documents/ 114097690/114438878/Sustainable+livelihood s+guidance+sheets.pdf/594e5ea6-99a9-2a4ef288-cbb4ae4bea8b?t=1569512091877
Fisheries Act 2002 (Act 625). Government of Ghana Publisher.

Fjellheim, A., \& Johnsen, B. O. (2001). Experiences from stocking salmonid fry and fingerlings in Norway. Nordic Journal of Freshwater Research, 20-36.

Food and Agriculture Organization (FAO). (2006). The State of the World Fisheries and Aquaculture. Rome: FAO.

Food and Agriculture Organization (FAO). (2008). Climate change and food security: A conceptual document. Rome, Italy: Food and Agricultural Organisation of the United Nations.

Food and Agriculture Organization (FAO). (2008). Soaring food prices: facts, perspectives, impacts and actions required. In High Level Conference on World Food Security: The Challenges of Climate Change and Bioenergy, 3-5 June 2008. FAO, Rome.

Fraga J., Salas S., \& Mexicano-Cíntora, G. (2008). La Pesca en Yucatán: de la abundancia a la escasez, a la fragilidad de las estructuras Institucionales. In: Fraga J., Villalobos G. J., Doyon S., Gracía, A. (eds.), Gobernanza costera en México: descentralización y manejo ambiental en la península de Yucatán. CINVESTAV-IPN, Unidad Mérida, Universidad Autónoma de Campeche, IDRC, México, pp 179-201.

GIS unit of Department of Geography and Regional Planning, University of Cape Coast, 2017.

Harter, D. E., Irl, S. D., Seo, B., Steinbauer, M. J., Gillespie, R., Triantis, K. A., ... \& Beierkuhnlein, C. (2015). Impacts of global climate change on the floras of oceanic islandsProjections, implications and current knowledge. Perspectives in Plant Ecology, Evolution and Systematics, 17(2), 160-183.

Hinz, H., Prieto, V., \& Kaiser, M. J. (2009). Trawl disturbance on benthic communities: chronic effects and experimental predictions. Ecological Applications, 19(3), 761-773. 
International Organisation for Migration. (2016). Global Migration Trends 2015 Factsheet. Retrieved from https://publications.iom.int/system/ files/global_migration_trends_2015_factsheet. pdf.

Iwasaki, S., Razafindrabe, B. H. N., \& Shaw, R. (2009). Fishery livelihoods and adaptation to climate change: a case study of Chilika lagoon, India. Mitigation and Adaptation Strategies for Global Change, 14(4), 339-355.

Johnson, T. (2012). Fisheries Adaptations to Climate Change. Alaska Sea Grant Marine Advisory Programme, 1-8.

Kaiser, M. J., Collie, J. S., Hall, S. J., Jennings, S., \& Poiner, I. R. (2002). Modification of marine habitats by trawling activities: prognosis and solutions. Fish and Fisheries, 3(2), 114-136.

Knoke, D., \& Yang, S. (2008). Social network analysis (Vol. 154). Sage.

Kydd, J., \& Dorward A (2001). The Washington consensus on poor country agriculture: Analysis, prescriptions and institutional gaps. Development Policy Review, 19(5), 467-478.

Lum Kong, A. (2002). Impacts of global climate changes on Caribbean fisheries resources: research needs. Global Environmental Change and Food Systems. Caribbean Food Systems. St Augustine, Trinidad: Developing a Research Agenda.

Mahon, R. (2002). Adaptation of fisheries and fishing communities to the impacts of climate change in the CARICOM region. Prepared for the CARICOM Fisheries Unit, Belize City, Belize, as input to the planning process for the project Mainstreaming Adaptation to Climate Change (MACC) of the Caribbean Centre for Climate Change (CCCC).

McCarty, J. J., Canziani, O. F., Leary, N. A., Dokken, D. J., \& White, K. S. (2001). Climate change 2001: impacts, adaptation, and vulnerability. Contribution of working group II to the Third assessment report of the intergovernmental panel on climate change
(No. 574.5222 C639co 2001). Cambridge University Press.

Mensah, C. A. (2012). Optimisation of profit in the artisanal marine fishing: a case study of Sekondi fishing harbour. Unpublished Doctoral dissertation.

Ofori-Danson, P. K., Apegyah, K., Asiedu, B., \& Atsu, D. K. (2012). Stock assessment study and fisheries management plan for the Bui Reservoir. Report Submitted to the Bui Power Authority, 104.

Olago, D., Marshall, M., Wandiga, S. O., Opondo, M., Yanda, P. Z., Kangalawe, R., \& Kirumira, E. (2007). Climatic, socio-economic, and health factors affecting human vulnerability to cholera in the Lake Victoria basin, East Africa. AMBIO: A Journal of the Human Environment, 36(4), 350-358.

Ravenstein, E. G. (1885). The laws of migration. Journal of the statistical society of London, 48(2), 167-235.

Rice, J. C., \& Garcia, S. M. (2011). Fisheries, food security, climate change, and biodiversity: characteristics of the sector and perspectives on emerging issues. ICES Journal of Marine Science, 68(6), 1343-1353.

Serrat, O. (2017). Social network analysis. In Knowledge solutions (pp. 39-43). Springer Singapore.

Sethi, S. A. (2010). Risk management for fisheries. Fish and Fisheries, 11(4), 341-365.

Shauri, Y. M. (2014). An Assessment of Savings and Credit Groups on Poverty Reduction: A Case of Rural Households in North Unguja. Doctoral dissertation. The Open University of Tanzania.

Siddiqui, T. (2012). Impact of migration on poverty and development. Migrating Out of Poverty Research Program Consortium Working Paper, 2.

Thorpe, A., Andrew, N., \& Allison, E. (2007). Fisheries and poverty reduction. CAB Reviews: Perspectives in Agriculture, Veterinary 
Science, Nutrition and Natural Resources, 2(85), 2-12.

United Nations. (2015). International Migration Report, 2015 Highlights. New York: United Nations.

Whittingham, E., Campbell, J., \& Townsley, P. (Eds.). (2003). Poverty and Reefs: A global overview. IMM., 2(1), 23-38.

Wilk, J., Andersson, L., \& Warburton, M. (2013). Adaptation to climate change and other stressors among commercial and small-scale South African farmers. Regional environmental change, 13(2), 273-286.

World Bank. (2008). The sunken billions. The economic justification for fisheries reform. Washington, DC: Agriculture and Rural Development Department, the World Bank.

World Fish Center. (2009). Fish supply and food security for Africa. Flyer 1995. Penang, Malaysia: The World Fish Center. 